\title{
PENGEMBANGAN KEMAMPUAN BERBAHASA MELALUI METODE CERITA DENGAN MEMBACAKAN BUKU CERITA BERMEDIA GAMBAR PADA ANAK PRA SEKOLAH
}

Arifal Aris ${ }^{1}$, Andri Tri Kusumaningrum ${ }^{2}$

Sekolah Tinggi Ilmu Kesehatan Muhammadiyah Lamongan

Kutipan : Aris, A.,\& Kusumaningrum (2017). Pengembangan Kemampuan Berbahasa Melalui Metode Cerita Dengan Membacakan Buku Cerita Bermedia Gambar Pada Anak Pra Sekolah. Jurnal Kepertawatan Muhammadiyah,

\section{INFORMASI}

\section{Korespondensi : arifal.aris9@gmail.com}

\section{Keyword :}

Storytelling method, Language development of preschoolers

\section{A B S T R A C T}

This research is motivated by learning for develop of language ability on preschoolers. Based on preliminary survey conducted at kindergarten Aisyiah Bustanul Athfal (ABA) II Made Lamongan still get the delay of child language development which can affect the learning process. One of the interventions to develop children's speaking skills need to be done in the right way, one of them by using picture story method.

Research design using pra-experimental design with onegroup Pre-Post Test Design. Population of 47 using simple random sampling. Independen variabel of storytelling method, dependent variable of child language development. Technique of collecting data using Denver Development Screning Test I I ( DDST) sheets. Data was tabulated and analyzed using wilcoxon test with significant level $\alpha<0.05$.

The result showed that the language development of preschoolers 4-6 years at kindergarten ABA II Made before intervention 29 children (69\%), after done picture meth result 40 childre $(95,2 \%)$. Result wilcoxcon test, with a value of $p=0.001$ where $\mathrm{p}<0.05$, then rejected or capted, it means there is influence of storytelling method on language develop in kindergarten ABA II Made sub district Lamongan distric Lamongan.

The need for the development of teaching activities in kindergarten by adding a storytelling method to stimulate the language development of children so as to provide a new learning experience for children. 


\section{PENDAHULUAN}

Perkembangan merupakan suatu perubahan yang berlangsung seumur hidup dengan bertambahnya struktur dan fungsi tubuh yang lebih kompleks dalam kemampuan gerak kasar, gerak halus, bicara dan bahasa serta sosialisasi dan kemandirian. Ciri-ciri pertumbuhan dan perkembangan anak antara lain, menimbulkan perubahan, berkolerasi dengan pertumbuhan, memiliki tahap yang berurutan dan mempunyai pola yang tetap. Perkembangan berbicara dan menulis merupakan suatu proses yang menggunakan bahasa ekspresif dalam membentuk arti. Perkembangan berbicara saat awal dari anak yaitu menggumam maupun membeo. Menurut pendapat Dyson bahwa perkembangan berbicara terkadang individu dapat menyesuaikan dengan keinginannya sendiri, hal ini tidak sama dengan kegiatan menulis (Nurbiana, 2008).

Seorang bayi dari hari ke hari akan mengalami perkembangan bahasa dan kemampuan bicara, namun tentunya tiap anak tidak sama persis pencapaiannya, ada yang cepat berbicara ada pula yang membutuhkan waktu agak lama. Untuk membantu perkembangannya ibu dapat membantu memberikan stimulasi yang disesuaikan dengan keunikan masing-masing anak. Sejalan dengan perkembangan kemampuan serta kematangan jasmani terutama yang bertalian dengan proses bicara, komunikasi tersebut makin meningkat dan meluas, misalnya dengan orang disekitar lingkungannya dan berkembang melalui orang lain yang baru dikenal atau yang bersahabat dengannya.

(Syakir Abdul Azhim,2011). Terdapat perbedaan yang signifikan antara pengertian bahasa dan berbicara. Bahasa mencakup segala bentuk komunikasi, baik yang diutarakan dalam bentuk lisan, tulisan, bahasa isyarat, bahasa gerak tubuh, ekspresi wajah pantomim atau seni. Sedangkan bicara adalah bahasa lisan yang merupakan bentuk yang paling efektif untuk berkomunikasi dan paling penting serta paling banyak dipergunakan. Perkembangan bahasa tersebut selalu meningkat sesuai dengan meningkatnya usia anak. Orangtua sebaiknya selalu memperhatikan perkembangan tersebut, sebab pada masa ini, sangat menentukan proses belajar. Hal ini dapat dilakukan dengan memberi contoh yang baik, memberikan motivasi pada anak untuk belajar dan sebagainya (Departemen Pendidikan nasional, 2007)
Dalam pembelajaran pendidikan di Taman Kanak-kanak, seorang guru harus memahami bagaimana peran dan fungsi metode bercerita dalam mengembangkan kemampuan berbahasa anak, seperti kemampuan berbahasa secara reseptif (understanding) yang bersifat pengertian, dan kemampuan berbahasa secara ekspresif (producing) yang bersifat pernyataan. Anak usia Taman Kanak-kanak berada dalam fase perkembangan bahasa secara ekspresif. Hal ini berarti anak telah dapat mengungkapkan keinginannya, penolakannya, maupun pendapatnya dengan menggunakan bahasa lisan (Santrock, John W 2007).

Bahasa merupakan alat komunikasi sebagai wujud dari kontak sosial dalam menyatakan gagasan atau ide-ide dan perasaan-perasaan oleh setiap individu sehingga dalam mengembangkan bahasa yang bersifat ekspresif, seorang anak memerlukan cara yang sesuai dengan tingkat perkembangan usia taman kanak-kanak dengan memperhatikan faktor-faktor yang mempengaruhi pribadi anak tersebut. Menurut Giliwati, Desak Made,dkk.2013 Melalui bercerita, dapat membantu mereka dalam mengembangkan dan melatih kemampuan bahasa yang anak-anak miliki dan dengan melalui cerita anak lebih dituntut aktif dalam mengembangkan bahasanya khususnya bahasa ekspresif dibantu oleh arahan dan bimbingan guru. Metode bercerita memang sesuatu yang sangat menarik, karena metode tersebut sangat digemari anakanak, apalagi jika metode yang digunakan ditunjang dengan penggunaan bahasa yang sederhana dan mudah dipahami anak-anak, sehingga anak lebih berpotensi dalam mengembangkan bahasa yang sifatnya ekspresif (Jasmine, 2011).

Berdasarkan ikatan dokter Anak Indonesia, sekitar 5-8\% anak prasekolah terjadi keterlambatan dalam perkembangan bahasa (Silvia Audya Perdana et al). Hasil survey awal penelitian, dari 15 anak didapatkan 4 (26\%) anak terjadi ketelambatan dalam berbicara dengan menggunakan alat ukur DDST pada sumber Nogroho, Heru Santoso W.2009. Hal ini dapat dipengaruhi oleh metode yang digunakan dalam proses pembelajaran. Penggunaan metode maupun model pembelajarannya yang kurang menarik, sehingga proses pembelajaran yang terjadi mengalami ketidakberhasilan dengan hasil belajar yang dicapai oleh siswa kurang maksimal, anak cenderung bermain sendiri dan tidak 
memperhatikan. Karena itu penulis ingin menemukan jalan keluarnya dengan cara melaksanakan penelitian agar dapat diidentifikasikan permasalahan yang dilatarbelakangi tidak berhasilnya proses kegiatan belajar tersebut. Berdasarkan uraian di atas, maka peneliti tertarik untuk melakukan pengkajian lebih dalam mengenai "pengaruh metode cerita dengan membacakan buku cerita bergambar terhadap perkembangan bahasa anak prasekolah". Tujuan penelitian ini untuk diketahuinya pengaruh metode bercerita melalui buku cerita bermedia gambar terhadap perkembangan berbahasa pada anak pra sekolah.

\section{METODE}

Desain penelitian ini kuantitatif dengan jenis praexperimental design menggunakan One-group Pre-Post Test Design. Populasi sebesar 47 anak prasekolah dengan teknik sampling menggunakan simple random sampling, didapatkan sampel sebesar 42 anak diambil dari populasi yang sesuai kriteria inklusi ; 1) Anak prasekolah usia 4-6 tahun, 2) Ibu bersedia dilakukan penelitian. Terdapat 1 kelompok yang diukur sebelum dan sesudah perlakuan. Sebelum perlakuan dilakukan observasi perkembangan bahasa anak menggunakan lembar Denver Development Screning Test II (DDST). Kemudian diberikan intervensi bercerita dengan membacakan buku cerita bermedia gambar dilakukan dua kali dalam satu minggu selama delapan minggu, selanjutnya orang tua (ibu) diberikan penjelasan cara bercerita agar dapat melakukan mandiri dirumah dengan media buku cerita bergambar selama 4 minggu observasi menggunakan alat ukur checklist. Kemudian dilakukan post-test pada akhir minggu duabelas untuk observasi kemajuan perkembangan bahasa anak setelah intervensi dengan 3 interpretasi antara lain : normal, peringatan (suspect) dan tidak dapat diuji. Kemudian hasilnya ditabulasi dan dianalisa menggunakan uji wilcoxon.

\section{HASIL}

Responden dalam penelitian penelitian adalah anak prasekolah 4-6 tahun dan orang tua (ibu) di TK ABA II Made Kecamatan Lamongan Kabupaten Lamongan.

Tabel 1. Jenis Kelamin Anak Prasekolah Di TK ABA II Made Kecamatan Lamongan Tahun 2017

\begin{tabular}{|c|l|c|c|}
\hline No. & \multicolumn{1}{|c|}{$\begin{array}{c}\text { Jenis } \\
\text { Kelamin }\end{array}$} & Frekuensi & Prosentase (\%) \\
\hline 1 & Laki-laki & 18 & 42.9 \\
2 & Perempuan & 24 & 57.1 \\
\hline \multicolumn{2}{|c|}{ Total } & 42 & 100 \\
\hline
\end{tabular}

Sumber : Data Penelitian 2017

Dari tabel di atas dapat dijelaskan bahwa sebagian besar anak berjenis kelamin perempuan sebanyak 24 anak (57.1\%).

Tabel 2. Umur Anak Prasekolah Di TK ABA II Made Kecamatan Lamongan Tahun 2017.

\begin{tabular}{|c|c|c|c|}
\hline No. & Umur & Frekuensi & Prosentase (\%) \\
\hline 1 & $48-54$ bulan & 9 & 21.4 \\
2 & $55-60$ bulan & 15 & 35.7 \\
3 & $61-66$ bulan & 11 & 26.2 \\
4 & $67-72$ bulan & 7 & 16.7 \\
\hline \multicolumn{2}{|c|}{ Total } & 42 & 100 \\
\hline
\end{tabular}

Sumber : Data Penelitian 2017

Dari tabel di atas dapat dijelaskan bahwa sebagian besar anak berumur 55-60 bulan sebanyak 15 anak (35.7\%) dan sebagian kecil anak berumur 67-72 bulan sebanyak 7 anak $(16.7 \%)$.

Tabel 3. Umur Orang Tua Di TK ABA II Made Kecamatan Lamongan Tahun 2017.

\begin{tabular}{|c|c|c|c|}
\hline No. & Umur & Frekuensi & Prosentase (\%) \\
\hline 1 & $21-35$ tahun & 27 & 64.3 \\
2 & $>35$ tahun & 15 & 35.7 \\
\hline \multicolumn{2}{|c|}{ Total } & 42 & 100 \\
\hline
\end{tabular}

Sumber : Data Penelitian 2017

Dari data di atas menunjukkan bahwa sebagian besar orang tua berumur antara 21 sampai 35 tahun yaitu sebanyak 27 orang $(64.3 \%)$.

Tabel 4. Pendidikan Orang Tua Di TK ABA II Made Kecamatan Lamongan Tahun 2017.

\begin{tabular}{|c|l|c|c|}
\hline No. & Pendidikan & Frekuensi & Prosentase (\%) \\
\hline 1 & SMA & 36 & 85.7 \\
2 & D3 & 1 & 2.4 \\
3 & S1 & 5 & 11.9 \\
\hline \multicolumn{2}{|c|}{ Total } & 42 & 100 \\
\hline
\end{tabular}

Sumber : Data Penelitian 2017 
Dari tabel di atas menunjukkan bahwa hampir seluruhnyaorang tua memiliki latar belakang pendidikan terakhir Sekolah Menengah Atas (SMA) sebanyak 36 orang 85.7\%) dan sebagian kecil memiliki latar belakang pendidikan terakhir Diploma 3 sebanyak 1 orang $(2.4 \%)$.

Tabel 5. Pekerjaan Orang Tua Di TK ABA II Made Kecamatan Lamongan Tahun 2017.

\begin{tabular}{|c|l|c|c|}
\hline No. & \multicolumn{1}{|c|}{ Pekerjaan } & Frekuensi & Prosentase (\%) \\
\hline 1 & Ibu Rumah Tangga & 28 & 66.7 \\
2 & Wiraswasta & 4 & 9.5 \\
3 & Swasta & 8 & 19 \\
4 & PNS & 2 & 4.8 \\
\hline \multicolumn{2}{|c|}{ Total } & 42 & 100 \\
\hline
\end{tabular}

Sumber : Data Penelitian 2017

Dari data di atas menunjukkan bahwa sebagian besar orang tua memiliki latar belakang perkerjaan ibu rumah tangga sebanyak 28 orang (66.7\%).

Tabel 6. Perkembangan Bahasa Anak Sebelum Diberikan Kegiatan Bercerita dengan Buku Cerita Bermedia Gambar Pada Anak Usia 4-6 Tahun di TK ABA II Made Lamongan Tahun 2017

\begin{tabular}{|c|l|c|c|}
\hline No. & \multicolumn{1}{|c|}{$\begin{array}{c}\text { Perkembangan } \\
\text { Bahasa }\end{array}$} & Frekuensi & Prosentase (\%) \\
\hline 1 & Normal & 29 & 69.0 \\
2 & Suspek & 13 & 31.0 \\
3 & Tidak dapat diuji & 0 & 0 \\
\hline \multicolumn{2}{|r|}{ Total } & 42 & 100 \\
\hline
\end{tabular}

Sumber : Data Penelitian 2017

Berdasarkan tabel 3.6 di atas dapat dijelaskan bahwa perkembangan bahasa anak usia prasekolah di TK ABA II Made Kecamatan Lamongan sebelum diberikan kegiatan bercerita sebagian besar perkembangan bahasa anak normal sebanyak 29 anak (69\%) dan hampir sebagian mengalami suspek sebanyak 13 anak $(31 \%)$.

Tabel 7. Perkembangan Bahasa Anak Sesudah Diberikan Kegiatan Bercerita Pada Anak Usia 4-6 Tahun di TK ABA II Made Lamongan Tahun 2017.

\begin{tabular}{|c|c|c|c|}
\hline No. & $\begin{array}{c}\text { Perkembangan } \\
\text { Bahasa }\end{array}$ & Frekuensi & Prosentase (\%) \\
\hline
\end{tabular}

\begin{tabular}{|c|l|c|c|}
\hline 1 & Normal & 40 & 95.2 \\
2 & Suspek & 2 & 4.8 \\
\hline \multicolumn{2}{|c|}{ Total } & 42 & 100 \\
\hline
\end{tabular}

Sumber : Data Penelitian 2017

Berdasarkan tabel 5.7 di atas dapat dijelaskan bahwa perkembangan bahasa anak usia prasekolah di TK Made Kecamatan Lamongan sesudah diberikan kegiatan bercerita perkembangan bahasa hampir seluruhnya normal sebanyak 40 anak (95.2\%) normal.

\section{Tabel 8. Pengaruh Perkembangan Bahasa Menggunakan Bercerita Pada Anak Usia 4-6 Tahun di TK ABA II Made Kecamatan Lamongan Tahun 2017.}

\begin{tabular}{|c|c|c|c|c|c|c|}
\hline \multirow{3}{*}{$\begin{array}{c}\text { Perkembang } \\
\text { an Bahasa } \\
\text { Anak } \\
\text { Prasekolah } \\
\text { Sebelum } \\
\end{array}$} & \multicolumn{6}{|c|}{$\begin{array}{c}\text { Perkembangan Bahasa Anak Prasekolah } \\
\text { Sesudah Diberikan Kegiatan Bercerita }\end{array}$} \\
\hline & \multicolumn{2}{|c|}{ Normal } & \multicolumn{2}{|c|}{ Suspek } & \multicolumn{2}{|c|}{ Total } \\
\hline & $\Sigma$ & $\%$ & $\Sigma$ & $\%$ & $\Sigma$ & $\%$ \\
\hline Normal & 29 & $100.0 \%$ & 0 & $0.0 \%$ & 29 & $100.0 \%$ \\
\hline Suspek & 11 & $84.6 \%$ & 2 & $15.4 \%$ & 13 & $100.0 \%$ \\
\hline Total & 40 & $95.2 \%$ & 2 & $4.8 \%$ & 42 & $100.0 \%$ \\
\hline \multicolumn{7}{|c|}{$\mathrm{Z}=-3.317^{\mathrm{a}}$} \\
\hline
\end{tabular}

Sumber : Data Penelitian 2017

Berdasarkan tabel 3.8 di atas dapat dijelaskan bahwa dari $29(100 \%)$ anak yang perkembangan bahasanya normal sebelum dan sesudah dilakukan metode cerita. Sedangkan setelah dilakukan kegiatan bercerita sebagian besar perkembangan bahasanya normal sebesar 11 anak (84.6\%) dan sebagian kecil suspek sebesar 2 anak (15.4\%).

Berdasarkan hasil pengujian dengan uji wilcoxon dengan SPSS, didapat nilai $Z$ sebesar -3.317 . Dari tabel $Z$ untuk angka $Z_{\text {hitung }}=3.317$ didapat angka kumulatif sebesar 0,9995 . Hal ini berarti probabilitas adalah 1-0,9995 atau 0,0005. Karena uji 2 sisi, maka probabilitas (asymp. sig.) adalah 0.001 . Hasil $Z_{\text {hitung }}$ menjauhi angka kritiz $Z$ $\pm 1,96$, maka $\mathrm{H}_{0}$ ditolak, artinya terdapat pengaruh metode cerita dengan membacakan buku cerita bermedia gambar bercerita dengan buku bergambar terhadap perkembangan bahasa pada anak usia prasekolah di ABA II Made Kecamatan Lamongan Kabupaten Lamongan. (Nursalam.2013)

\section{PEMBAHASAN}


Setelah dilakukan uji analisa dan menguji hasil penelitian dengan menggunakan uji statistic diperoleh hasil yang cukup bervariasi yang memerlukan pembahasan tentang bagaimana perkembangan bahasa anak usia pra sekolah sebelum dilakukan bercerita, perkembangan bahasa anak usia pra sekolah setelah dilakukan bercerita dan pengaruh metode cerita dengan membacakan buku cerita bermedia gambar pada anak usia pra sekolah terhadap perkembangan bahasa.

1. Perkembangan Bahasa Anak Usia Pra Sekolah Sebelum Dilakukan Kegiatan Bercerita Dengan Membacakan Buku Cerita Bermedia Gambar

Berdasarkan tabel 6, dapat dijelaskan bahwa kemampuan bahasa anak TK ABA II Made Kecamatan Lamongan sebelum dilakukan kegiatan bercerita sebagian besar normal sebanyak 29 anak (69\%) dan sebagian hampir sebagian mengalami suspek sebanyak 13 anak (31\%). Dari data di atas dapat dijelaskan bahwa perkembangan bahasa anak sebagian besar normal. Perkembangan bahasa dipengaruhi oleh stimulus yang berupa rangsangan, dorongan dan kesempatan untuk melakukan komunikasi dengan anak ditunjukkan oleh kemampuan anak untuk dapat berbicara spontan seperti mengkomunikasikan keinginannnya, kejadian yang dialaminya, merespon suara, mengikuti perintah, mengungkapkan emosinya yang sesuai dengan tahapan usianya.

Opini tersebut sejalan dengan teori yang diungkapkan oleh Santrock, John W 2007 yaitu stimulasi pada perkembangan bahasa dapat dilakukan orang tua atau pengasuh disetiap kesempatan anak diajak bicara misalnya pada saat mandi, mengenakan baju, makan dan saatsaat lainnya. Perkembangan bahasa dapat berkembang jika anak ada kesempatan untuk belajar dan berlatih. Dengan ungkapan lain, kemampuan berbahasa sangat dipengaruhi oleh keadaan lingkungan sekitarnya yang mendukung misalnya melihat kita membaca buku, hal ini mengandung pesan bahwa membaca buku itu bermanfaat dan penting, dorong anak agar mau bercerita tentang apa yang dilihatnya.

Berdasarkan tabel 3, usia orang tua murid TK Aiasyah Bustanul Athfal (ABA) Made Kecamatan Lamongan sebagian besar berumur antara 21-35 tahun sebanyak 27 orang (64.3\%). Berdasarkan fakta di atas dapat diketahui bahwa sebagian besar orang tua murid termasuk tahap usia dewasa yang mana telah memiliki rasa tanggungjawab dan peran sebagai orang tua serta mulai aktif untuk mencari informasi tentang cara mendidik anak yang tepat. Keaktifan orang tua untuk mencari dan mengaplikasikan informasi mengenai perkembangan anak sangat berpengaruh terhadap perkembangan anak, karena semakin banyak pengetahuan orang tua maka semakin positif pola mendidik anak sehingga perkembangan anak juga semakin baik.

Opini tersebut didukung oleh teori menurut Notoadmodjo (2007), pada usia dewasa awal (21-35 tahun) seseorang memasuki taraf memelihara dan mempertahankan apa yang telah ia miliki yang akan berpengaruh terhadap cara mengasuh anak. Menurut, semakin bertambah umur, peran dan pengalaman yang dimiliki seseorang juga akan bertambah pada aspek fisik dan psikologis, perubahan pada fisik terjadi akibat pematangan fungsi organ dan psikologis menjadikan taraf berpikir seseorang menjadi semakin matang dan dewasa, matang dalam berpikir dan bekerja. Kematangan berpikir akan mempengaruhi model pola asuh orang tua. Berdasarkan penelitian Kumboyono (2013), pola asuh yang demokratis sangat memnunjang untuk perkembangan anak prasekolah.

Berdasarkan tabel 4, dapat dijelaskan bahwa pendidikan orang tua murid TK ABA II Made Kecamatan Lamongan hampir seluruhnya orang tua memiliki latar belakang pendidikan terakhir Sekolah Menengah Atas (SMA) sebanyak 36 orang $85.7 \%$ ) dan sebagian kecil memiliki latar belakang pendidikan terakhir Diploma 3 sebanyak 1 orang (2.4\%). Berdasarkan data tersebut diketahui hampir seluruhnya dari orang tua murid berpendidikan Menengah Atas (SMA). Jenjang pendidikan ini merupakan menengah atas sehingga dalam pemikiran dan mencerna suatu pengalaman baru untuk menambah pengetahuan masih mudah diterima. Pengetahuan tidak hanya diperoleh melalui pendidikan formal saja tetapi pendidikan non formal seperti melalui media massa yang akhir-akhir ini sangat mudah diakses juga dapat mempengaruhi seseorang dalam memperoleh informasi tentang perkembangan bahasa pada anak.

Opini tersebut didukung dengan teori Notoadmodjo (2007) bahwa informasi yang diperoleh dari berbagai sumber akan mempengaruhi tingkat pengetahuan seseorang. 
Bila seseorang banyak memperoleh informasi maka ia cenderung mempunyai pengetahuan yang lebih luas. Pengetahuan adalah hasil penginderaan manusia, atau hasil tahu seseorang terhadap objek melalui indera yang dimilikinya (mata, hidung, telinga, dan sebagainya).

Berdasarkan tabel 5, bahwa sebagian besar orang tua memiliki latar belakang perkerjaan ibu rumah tangga sebanyak 28 orang (66.7\%). Berdasarkan fakta tersebut dapat disimpulkan bahwa pekerjaan orang tua (ibu) sebagai ibu rumah tangga memiliki lebih banyak waktu untuk berinteraksi memberikan perhatian dan pendidikan kepada anak, sehingga perkembangan anak lebih baik. Opini di atas ditunjang oleh teori yang disampaikan oleh Soetjiningsih (2013), interaksi ibu dan anak sangat mempengaruhi proses pertumbuhan dan perkembangan anak. Seorang anak yang tidak diasuh oleh kedua orang tuanya pasti mengalami proses pertumbuhan dan perkembangan yang berbeda ketimbang anak yang diasuh oleh mereka. Menurut Sofiana,Naning 2012, perkembangan bahasa anak ditentukan oleh perhatian yang diberikan oleh orang tua kepada anaknya, sehingga dapat meningkatkan mutu kualitas perkembangan bahasa anak.

2. Perkembangan Bahasa Anak Usia Pra Sekolah Setelah Dilakukan Kegiatan Bercerita Dengan Membacakan Buku Cerita Bermedia Gambar Berdasarkan tabel 7, dapat diketahui bahwa setelah diberikan kegiatan bercerita perkembangan bahasa anak hampir seluruhnya atau 40 anak (95.2\%) normal. Dengan melihat data tersebut, maka secara umum dapat dikatakan bahwa perkembangan bahasa anak normal mengalami peningkatan. Hal tersebut dipengaruhi oleh kesempatan untuk belajar dan rangsangan yang mudah dan tepat yang diberikan untuk meningkatkan perkembangan bahasa anak, salah satunya melalui bercerita dengan media buku bergambar. Dengan kegiatan ini anak-anak dapat mudah mengingat kembali informasi yang pernah diterimanya melalui ilustrasi gambar pada buku cerita sehingga sangat mudah diterima dan dipahami si anak dengan caranya sendiri yaitu dengan membaca gambar dan dapat melatih pola pikir anak serta membentuk kepribadian anak berdasarkan cerita yang ada didalamnya.

Opini tersebut didukung oleh teori Nurbiana (2008), bila cerita yang disampaikan pada anak terlalu panjang dan terinci dapat dengan menambahkan ilustrasi gambar dari buku yang dapat dapat menarik perhatian anak, maka teknik bercerita itu akan berfungsi dengan baik. Penggunaan ilustrasi gambar dalam bercerita dimaksudkan untuk memperjelas pesanpesan yang dituturkan, juga untuk mengikat perhatian anak pada jalannya cerita. Bercerita dengan media buku cerita bergambar dapat mengembangkan daya imajinasi mengartikan dari tampilan gambar pada buku cerita serta melatih konsentrasi. Menurut penelitian Ariswijaya.2011, pengrtahuan ibu dan pemberian stimulasi bahasa dapat m,eningkatkan kecerdasan berbahsa pada anak usia toddler. Stimulasi dapat diberikan secara bervariasi salah satunya dengan bermain kartu dapat meningkatkan perkembnagn bahasa naka pada usia 4-5 tahun. (Puji L, Hermawati DS).

Berdasarkan tabel 2, dapat diketahui bahwa sebagian besar anak berumur 55-60 bulan sebanyak 15 anak (35.7\%) dan sebagian kecil anak berumur 67-72 bulan sebanyak 7 anak (16.7\%). Dari data tersebut dapat disimpulkan bahwa sebagian besar anak berumur antara 55 sampai 60 bulan. Pada usia tersebut urat saraf dan otot alat bicara berkembang sejalan dengan rasa ingin tahu serta sikap antusias yang tinggi, sehingga timbul pertanyaan-pertanyaan dari anak dengan kemampuan bahasanya.

Opini tersebut didukung oleh teori menurut Farida Nur'aini (2009) bahwa di usia 5 tahun anak telah memiliki kemampuan berbahasa berkembang dengan pesat mengalami peningktana jumlah kosakata yang begitu pesat. Kata-kata yang anak miliki mulai digunakan untuk memahami konsep-konsep di sekitarnya, mengeksplorasi lingkunagn di sekitarnya dengan bahasa. Sehingga bisanya anak akan banyak bertanya. Perkembangan kemampuan berbahasa akan terjadi pada 2 aspek yaitu kemampuan ekspresif untuk menghasilkan suara atau kata secara lisan, isyarat, gesture atau bentuk tertulis untuk menyampaikan pesan. Kemampuan reseptif adalah kemampuan untuk memproses dan memahami pesan dari bahasa baik tertulis, lisan dan gesture maupun isyarat.

Berdasarkan tabel 1, dapat diketahui bahwa sebagian besar responden berjenis kelamin perempuan sebanyak 24 anak (57.1\%). Dari fakta di atas dapat diketahui bahwa kebanyakan anak yang diteliti berjenis kelamin perempuan. Jenis kelamin merupakan bawaan sejak lahir untuk membedakan seseorang dalam perilaku, emosional, peran dan sifat. Anak perempuan 
lebih telaten, patuh dan mudah diarahkan/diatur, sedangkan anak laki-laki mudah bosan, banyak tingkah, dan tidak telaten untuk melakukan aktivitas tertentu. Hal tersebut yang membuat anak laki-laki lebih lambat pertumbuhan dan perkembangannya daripada anak perempuan.

Opini tersebut sesuai dengan teori Hidayat, Aziz Alimul.2009, bahwa anak perempuan lebih mudah diatur dan tenang berbeda dengan anak laki-laki yang cenderung banyak tingkah, lebih sulit diatur, sering membantah orang tua dan susah diarahkan. Anak laki-laki cenderung lebih lambat tumbuhnya dari pada anak perempuan. Berdasarkan hasil penelitian Victor (2012) menununjukkan keterlambatan perkembangan bahasa mengalami peningkatan setelah diberikan stimulasi pembelajaran.

\section{Pengaruh Metode Cerita Dengan Membacakan Buku Cerita Bermedia Gambar Terhadap Perkembangan Bahasa Anak Usia Pra Sekolah}

Berdasarkan tabel 8 , di atas dapat
dijelaskan bahwa dari 29 anak yang perkembangan bahasanya normal sebelum dilakukan kegiatan bercerita dengan membacakan buku cerita bermedia gambar, dimana setelah dilakukan metode cerita perkembangan bahasa seluruhnya 29 anak dan dari 13 anak yang perkembangan bahasanya suspek sebelum diberikan metode bercerita, dimana setelah diberikan bercerita sebagian besar perkembangan bahasanya normal sebesar 11 anak (84.6\%) dan sebagian kecil suspek sebesar 2 anak (15.4\%). Masih adanya sebagian kecil anak dengan perkembangan bahasa suspek setelah diberikan metode bercerita diakibatkan oleh kemauan atau antusias anak untuk melakukan kegiatan kurang dan dapat juga karena mereka mudah bosan dengan kegiatan yang sedang mereka lakukan.

Berdasarkan hasil pengujian dengan uji wilcoxon dengan SPSS, didapat nilai $Z$ sebesar 3.317. Dari tabel $Z$ untuk angka $Z_{\text {hitung }}=$ 3.317didapat angka kumulatif sebesar 0,9995. Hal ini berarti probabilitas adalah 1-0,9995 atau 0,0005 . Karena uji 2 sisi, maka probabilitas (asymp. sig.) adalah 0.001 . Hasil $Z_{\text {hitung }}$ menjauhi angka kritiz $\mathrm{Z} \pm 1,96$, maka $\mathrm{H}_{0}$ ditolak atau $\mathrm{H}_{1}$ diterima, artinya terdapat pengaruh metode bercerita terhadap perkembangan bahasa pada anak usia prasekolah di TK ABA II Made Kecamatan Lamongan Kabupaten Lamongan.

Kajian di atas menunjukkan bahwa kegiatan bercerita yang diberikan pada anak usia prasekolah di TK ABA II Made Kecamatan Lamongan Kabupaten Lamongan memiliki pengaruh yang signifikan terhadap perkembangan bahasa anak, sehingga dapat dikatakan pula bahwa kegiatan bercerita ini dapat diterapkan untuk membantu anak usia prasekolah dalam mengembangkan bahasanya. Dengan demikian bercerita bisa meningkatkan perkembangan bahasa usia prasekolah di Taman Kanak-kanak ABA II Made Kecamatan Lamongan.

Opini tersebut didukung oleh teori yang dikemukakan oleh Muhammad T, Hayati, risnita, (2016), bahwa kegiatan bercerita dapat membantu anak dalam mengembangkan bahasanya karena kegiatan ini dapat menambah perbendaharan kosakata dan memudahkan untuk mengingatnya, menyalurkan imajinasi fantasi. Mendongeng merangsang anak untuk berbicara, bertanya tentang pesan gambar sesuai dengan yang anak lihat. Bercerita yang efektif dapat mempengaruhi cara berfikir dan cara berperilaku anak karena mereka senang mendengarkan cerita walaupun dibaca berilang -ulang. Sedangkan berdasarkan penelitian Giliwati, Desak Made,dkk (2013), menunjukkan terjadi peningkatan signifikan pada perkembgangan bahasa anak setelah diberikan bercerita berbantuan Media Gambar Model Accordion.

\section{KESIMPULAN}

Berdasarkan hasil penelitian dan pembahasan yang telah disajikan, maka dapat ditarik beberapa kesimpulan antara lain : Perkembangan bahasa anak prasekolah di TK ABA II Made Kecamatan Lamongan Kabupaten Lamongan sebelum diberikan kegiatan bercerita dengan media buku cerita bergambar sebagian besar normal sebesar $69 \%$. Sedangkan perkembangan bahasa anak setelah diberikan kegiatan bercerita dengan media buku cerita bergambar hampir seluruhnya perkembangan bahasa anak usia prasekolah di TK ABA II Made Kecamatan Lamongan Kabupaten Lamongan normal sebesar 95.2\%. Berdasarkan hasil uji statistik, menunjukkan terdapat pengaruh metode cerita dengan media buku cerita bergambar terhadap perkembangan bahasa pada anak prasekolah di ABA II Made Lamongan Kabupaten Lamongan. Hal tersebut 
sesuai dengan teori Farida (2009) bahwa kegiatan bercerita, mendongeng dapat merangsang perkembangan bahasa anak.

\section{SARAN}

Berdasarkan hasil yang ditemukan dari keterbatasan penelitian, maka yang dapat menjadi saran adalah sebagai berikut : bagi peneliti selanjutnya dapat mengembangkan penelitian dengan menghubungkan faktor-faktor lain yang mempengaruhi terjadinya perkembangan bahasa yang tidak sesuai dengan usia perkembangan (suspect), menambah populasi agar hasinya lebih valid dan representative, serta memperpanjang waktu intervensi. Bagi orang tua :: Meningkatkan minat dan ketekunan untuk memberikan stimulasi dengan bercerita yang dapat meningkatkan perkembangan bahasa anak. Bagi pendidik, dapat mengembangkan metode pembelajaran pada anak prasekolah dengan metode bercerita dengan media gambar sehingga dapat menambah pengalaman baru bagi anak, melatih imajinatif, serta merangsang kemampuan ekspresif dan reseptif.

\section{DAFTAR PUSTAKA}

Ariswijaya.2011.Hubungan pengetahuan dan stimulasi bahasa oleh ibu dengan perkembangan bahasa anak usia toodler.http : www.uny.ac.id. Diakses tanggal 16 Pebruari 2016

Departemen Pendidikan nasional .2007. Pedoman pembelajaran bidang pengembangan berbahasa di taman Kanak-kanak . Jakarta : Direktorat Pembinaan Taman Kanak-kanak dan sekolah dasar

Farida Nur'aini, Ma... Dongengin Aku Yuuk!, (Surakarta: Afra Publishing, 2009) h.10-11

Giliwati, Desak Made,dkk.2013.Penerapan Metode bercerita berbantuan Media Gambar Model Accordion untuk meningkatkan kemampuan berbahasa pada anak kelas TK B. diakses tanggal 20 Januari 2016

Hidayat, Aziz Alimul.2009.Pengantar Ilmu Keperawatan Anak I.jakarta : Salemba Medika

Jasmine Hana, Terapi Kecerdasan Anak
Dengan Dongeng, (Yogyakarta: Berlian Media, 2011) h.68

Kumboyono, dkk, 2013.Hubungan Pola Asuh dengan perkembangan bahasa anak usia prasekolah di poyandu mawar wilayah kerja pekesmas ampah kecamatan dusun tengah kabupaten baroto timur 2013.http://old.fk.ub.ac.id/artikel/id/filedownl oad/keperawatan/sri\%20 hayati.pdf, diakases tanggal 20 januari 2016

Muhammad T, Hayati, risnita.2016, Mengembangkan kecerdasan bahasa anak usia dini melalui penggunaan metode bercerita bergambar di taman kanak-kanak al -jamiah dharma wanita iaian sts jambi.jurnal pendidikan tematik dikdas inversitas jambi. Eissn 2527-6905 vol 1(1) 2016 page2 14-22

Nurbiana Dhieni dkk., 2008 . Metode Pengembangan Bahasa, Jakarta: UT h. 68

Nursalam.2013.Metode Penelitian Ilmu Keperawatan Edisi 3.Jakarta : Salemba Medika

Nogroho, Heru Santoso W.2009. Petunjuk Praktis Denver Development Screening Test. Jakarta:EGC

Notoatmodjo, S. 2007.Promosi Kesehatan dan Ilmu Perilaku.Jakarta : Rineka cipta

Puji L, Hermawati DS. Pengembangan berbahasa pada anak 4-5 tahun melalui metode bermain kartu huruf. Jurnal care volume 03 nomor 2 januari 2016. PG PAUD IKIP PGRI Madiun

Santrock, John W 2007.Perkembangan anak Edisi Kesebelas Jilid I Terjemahan oleh Mila Rahmawati dan Anna kuswanti.Jakarta.Erlangga

Silvia Audya Perdana, Bernie Endyarni Medise, Erni Hernawati Purwaningsih. 2017. Duration Of Watching Tv And Child Language Development In Young Children Paediatrica Indonesiana Vol.57, No 2, March 2017 p.ISSN 0030; E-ISSN 2338-476X 
Soetjiningsih. (2013). Tumbuh Kembang dan Permasalahannya. Jakarta : sagung Seto

Sofiana,Naning 2012.Pengaruh Story telling terhadap perkembangan bahasa pada anak usia prasekolah.Mojokerto: STIKES Bina Sehat PPNI

Syakir Abdul Azhim, Membimbing Anak Terampil Berbahasa, (Depok: Gema Insani Press, 2011) h. 37-38

Victor A, Ana M.Angeles A, 2012. clinical implications of early differential diagnostic between language delay (LD) and specific language impairment (SLI).univ psycho v.11 No 1 PP.279-291. ENE-Mar 2012 EISSN 2011-2777

\section{ACKNOWLEDGMENT}

Ucapan terimakasih kami sampaikan kepada ristekdiksi yang telah mendanai penelitian ini, ketua STIKES Muhammadiyah Lamongan yang telah memberikan kesempatan dan ijin untuk melakukan penelitian dan Kepala sekolah TK ABA II Made-Lamongan yang telah memberikan fasilitas tempat penelitian serta seluruh responden yang telah kooperatif selama pengambilan data penelitian. 
